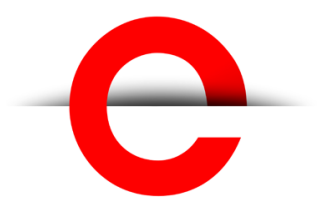

U T S

e PRES S
International Project

Management

Association Research

Conference 2017

2-4 November 2017

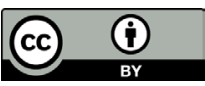

(c) 2018 by the author(s). This is an Open Access article distributed under the terms of the Creative Commons Attribution 4.0 International (CC BY 4.0) License (https:// creativecommons.org/licenses/ by/4.0/J, allowing third parties to copy and redistribute the material in any medium or format and to remix, transform, and build upon the material for any purpose, even commercially, provided the original work is properly cited and states its license.

Citation: Kim, K. P. and Kang, C. W. 2018. Exploring Project Management Research Trends for Project Success. International Project Management Association Research Conference 2017. UTS ePRESS, Sydney: NSW, pp.1-14. https:// doi.org/10.5130/pmrp. ipmarc2017.5647

Published by UTS ePRESS I http://pmrp.epress.lib.uts. edu.au
CONFERENCE PAPER

\section{Exploring Project Management Research Trends for Project Success}

\author{
Ki Pyung Kim ${ }^{1}$, Chang Wook Kang ${ }^{2 *}$ \\ 1 University of South Australia, School of Natural and Built Environments, Adelaide, South \\ Australia 5000, Australia \\ ${ }^{2}$ Hanyang University, Sangroku-gu, Ansan-si, Gyeonggi-do 426-791, South Korea.
}

*Corresponding author: Chang Wook Kang. cwkang57Qhanyang.ac.kr

Name: International Project Management Association Research Conference 2017

Location: Incheon, Republic of Korea

Dates: $2^{\text {nd }}$ to $4^{\text {th }}$ November 2017

Host Organisation: IPMA-Korea

DOI: https://doi.org/10.5130/pmrp.ipmarc2017.5647

Published: 08/06/2018

\section{Synopsis}

Given relentless global competition, project management (PM) success has become more vital than ever. In response to the gravity of PM, a large volume of PM research has been conducted in a broad context in recent decades. Despite the increasing volume of literature, the evolving research trend in PM has not been able to broaden understanding of PM success and respond to the dynamic change in a global PM.

\section{Relevance for practice/education}

This research provides an insight for industry and academia to forecast future direction of PM research and practice based on the past PM trends.

\section{Research design}

This research conducted desktop literature research as the primary research method to identify the PM research trends. In order to appreciate PM research trends, research articles published in the International Journal of Project Management from 1983 to 2016 were examined. A comparative analysis was used to explore the reciprocal relationship between the PM research 
U T S

e PRES S

trends and socioeconomic trends. In order to identify global issues, reports released by the United Nations from 1980 to 2016 were reviewed, and keywords search for matching PM research and global issue trends.

\section{Main findings}

A total of 70 countries contribute to publishing 2,015 articles, and the most frequently researched topics are HR, communication, and procurement (53\% of total research topics). The first occurrence of International PM and Programme management research was 1983, and the global PM body of knowledge development for PM success started from 1995. However, $41 \%$ (828 articles) of total articles are written based on developed countries including the UK, US and Australia. For a better understanding of global PM insights, more global collaboration among researchers in both developed and developing countries is required.

\section{Research implications}

This research will contribute to understanding PM research trends in conjunction with socioeconomic perspective, and serve as a stepping stone to develop further research on PM research trends and correlation with socioeconomic events in a quantified manner.

\section{Keywords}

Project Management, Research Trends, Knowledge Area, Project Management Success

\section{Introduction}

Given relentless global competition, PM has become more vital than ever. PM provides great value to various industry, organizations, and countries. It is a methodology to improve collaboration among key project stakeholders and enhance timely integration of essential project information based on better communication. PM is perceived as an organizational enabler to deliver business value to stakeholders and achieve their strategies effectively and efficiently (Crawford \& Pennypacker 2001). PM has been increasingly recognized as a process and a method to achieve growth and improvement in government organizations (Archibald 2003).

Indeed, it is forecasted that project oriented jobs will grow by an average of $33 \%$ by 2027 in 11 countries such as UK, US, China, and India (PMI 2017). The growth of project management practice and project managers is expected to contribute to a nation's productivity, since project management skills are essential to achieving project success that is not easily obtained by outsourcing human resources (Aron 2005). PM practices have evolved to accommodate the needs of new industrial fields and countries, and PM research for new application of PM knowledge continues to grow and evolve (Crawford et al. 2006).

In response to the importance of PM knowledge, a large volume of PM research has been conducted in a broad context. Academic PM research supplies new ideas for industrial fields to improve process and practice, and trends of PM research are presented as industry continues to adopt and implement the ideas. As the reciprocal relationship is presented between the academic research and industrial practices, there has been little research to identify emerging and future research questions based on the research trends and patterns, and also to establish cumulative insights and knowledge to support strategic decisions of industrial sectors (Crawford et al. 2006). 
U T S

e PRES S

The evolving PM research trends have been incompletely identified after 2006. Hence, this research aims to broaden understanding of PM research trends and the dynamic changes in a global PM context by examining the mutual influences between the PM research and society. This research will contribute to establishing an up to date understanding of PM research trends, so researchers can adjust their research focus toward more practical and timely issues, and provide a better understanding about the correlation between global socioeconomic events and PM research trends to the relevant PM professionals.

\section{Previous Research and Data Analysis}

To enhance organizational and national competitiveness, it is important to forecast PM research agenda into the future to select relevant and meaningful research direction and questions. (Jeong \& Kim 2012). Crawford et al. (2006) found that various PM research has changed the approach to projects in various industrial fields, and contribute to developing new methodologies to fill the practical gaps in knowledge of PM.

Researchers argue that understanding trends and patterns in PM research can give an in-depth understanding of holistic perspective regarding PM. Although it is important to obtain a holistic viewpoint of PM research trends, Evaristo and Fenema (1999) recognized that the most of PM research has been conducted in the construction industry, on large capital investments with diverse stakeholders (Betts \& Lansley 1995). Ilter and Ergen (2015) assert that more research focus should be given to under-researched sectors or topics that can lead to new ideas and approaches for a project.

In order to appreciate how PM research has evolved over time and across industry, it is essential to identify how PM research has addressed new challenges, with tools, techniques, and approaches. However, past research on PM mainly focused on specific domain knowledge such as communication, human resource, and risk management (Shenhar 1996; Stretton 2000). Other researchers mainly focused on general research topics in a specific period (Pascale 1990; Clarke \& Clegg, 1998). Consequently, researchers began to investigate PM research trends and patterns over time to obtain more meaningful insights from the historical data (Urli \& Urli 2000; Themistocleous \& Wearne 2000). Particularly, more extensive research on PM trends and patterns over time was carried out by various researchers to predict future trends.

In 2000 Kloppenborg and Opfer (2000) conducted research covering the period 1960 to 1999, supported by the Project Management Institute, and Themistocleous and Wearne (2000) conducted similar research focusing on published articles in International Journal of Project Management from 1984 to 1998 . While researchers contribute to revealing the trends of PM research topics, the relationship between PM research trends and events or issues within society has not been discovered. This research aims to identify PM research topics and trends over 35 years, and more importantly reveal a correlation between global socioeconomic events and PM research trends that can practically support industry and academia. This research will provide insights into academia and industry to guide future directions of their research and corporate strategies based on the PM research trends.

\section{Methodology}

This research conducted a desktop literature research as the primary research method to identify PM research trends and the socioeconomic events that influence industry globally. Based on the findings from the literature review, a comparative analysis was conducted to examine the relationship between PM research and industry by mapping PM research trends 
U T S

e PRESS and socioeconomic events. The scope of research was 35 years of research articles (1983 to 2016) published in the International Journal of Project Management (IJPM). IJPM was selected as a data source for the desktop literature research to minimise biased perspective, as the IJPM is one of the most prestigious academic journals (Lu et al. 2015). Furthermore, the IJPM is written in English, which is the most familiar language adopted as a de facto standard, although there are various prestigious journals in other countries including German, France, and US. More importantly, since various previous research covering global PM research trends has been reviewed and published in the IJPM, it is evident that the research scope of IJPM is highly aligned and relevant to the objective of this study. Volk et al. (2014) recommended investigating one specific reliable journal to secure the consistency of research topics and identify meaningful trends rather than including a wider domain of journals in data selection. A keyword and abstract reviews were carried based on the global PM standard ISO 21500 (ISO, 2012) because there is a possibility that a researcher could interpret the trends based on personal perspective and experience. The information regarding socioeconomic events was retrieved from reliable professional research organization and academic research databases, such as the Economic and Social Research Council UK, Elsevier, and Taylor \& Francis.

\section{Result and Discussion}

The number of research articles has continuously increased, as shown in Figure 1. In 1993, the number of articles was the lowest (26), and the largest volume of research was in 2015 (146). As more lessons from the past projects have been accrued and technology has advanced, more PM research has been conducted on various research topics.

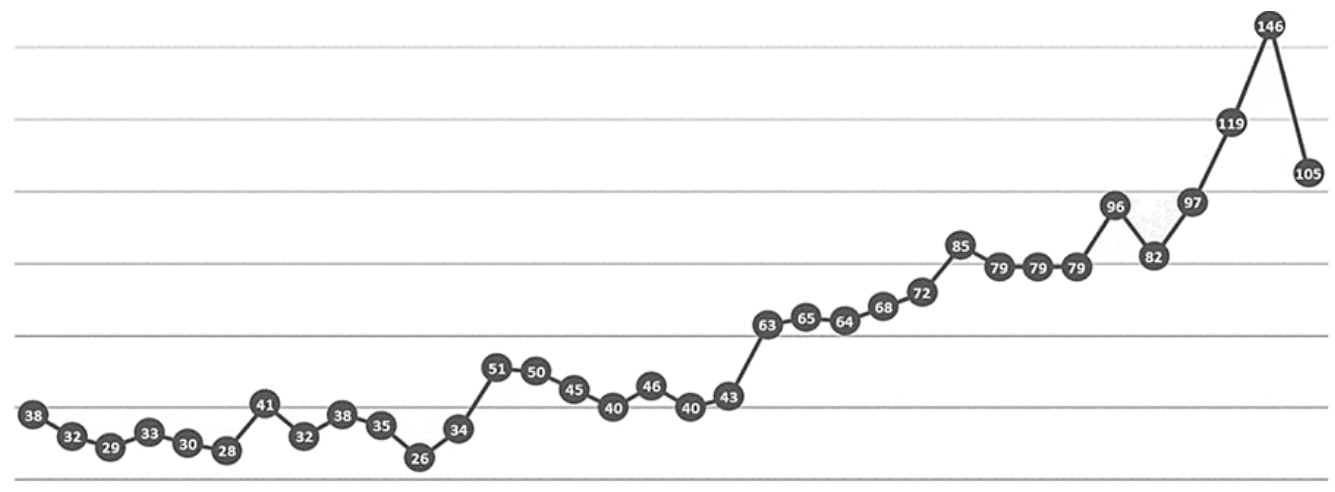

$\begin{array}{llllllllllllllllllllllllllllllllllllllllll}1 & 1 & 1 & 1 & 1 & 1 & 1 & 1 & 1 & 1 & 1 & 1 & 1 & 1 & 1 & 1 & 1 & 2 & 2 & 2 & 2 & 2 & 2 & 2 & 2 & 2 & 2 & 2 & 2 & 2 & 2 & 2 & 2 & 2\end{array}$

$\begin{array}{lllllllllllllllllllllllllllllllllll}9 & 9 & 9 & 9 & 9 & 9 & 9 & 9 & 9 & 9 & 9 & 9 & 9 & 9 & 9 & 9 & 9 & 0 & 0 & 0 & 0 & 0 & 0 & 0 & 0 & 0 & 0 & 0 & 0 & 0 & 0 & 0 & 0 & 0\end{array}$

$\begin{array}{llllllllllllllllllllllllllllllllll}8 & 8 & 8 & 8 & 8 & 8 & 8 & 9 & 9 & 9 & 9 & 9 & 9 & 9 & 9 & 9 & 9 & 0 & 0 & 0 & 0 & 0 & 0 & 0 & 0 & 0 & 0 & 1 & 1 & 1 & 1 & 1 & 1 & 1 \\ 3 & 4 & 5 & 6 & 7 & 8 & 9 & 0 & 1 & 2 & 3 & 4 & 5 & 6 & 7 & 8 & 9 & 0 & 1 & 2 & 3 & 4 & 5 & 6 & 7 & 8 & 9 & 0 & 1 & 2 & 3 & 4 & 5 & 6\end{array}$

Figure 1 Trend of the volume of research publication

A total of 70 countries, based on nationality of the first author, have contributed to publishing 2,015 articles over 35 years as shown in Table 1.828 articles (41\%) of total research has been conducted by the three major developed countries - the UK, US and Australia, and 39 out of 70 countries published only 106 articles. Developed countries have engaged much more actively in PM research and influence other developing and developed countries. 
Table $1 \quad$ Number of articles and country in IJPM

\begin{tabular}{|c|c|c|c|c|c|}
\hline Country & $\begin{array}{l}\text { Number } \\
\text { of articles }\end{array}$ & Country & $\begin{array}{c}\text { Number } \\
\text { of } \\
\text { articles }\end{array}$ & Country & $\begin{array}{l}\text { Number } \\
\text { of articles }\end{array}$ \\
\hline UK & 504 & South Africa & 16 & Slovenia & 3 \\
\hline US & 164 & Belgium & 14 & Bangladesh & 2 \\
\hline Australia & 160 & Malaysia & 14 & Croatia & 2 \\
\hline China & 96 & Austria & 12 & Cyprus & 2 \\
\hline Hong Kong & 79 & Iran & 12 & Zambia & 2 \\
\hline Canada & 75 & New Zealand & 12 & Armenia & 1 \\
\hline Netherlands & 71 & Egypt & 11 & Bulgaria & 1 \\
\hline Finland & 70 & Portugal & 9 & Fiji & 1 \\
\hline Taiwan & 70 & Russia & 8 & Haiti & 1 \\
\hline Sweden & 69 & Jordan & 7 & Iceland & 1 \\
\hline Singapore & 55 & Kuwait & 7 & Kenya & 1 \\
\hline German & 54 & $\begin{array}{l}\text { United Arab } \\
\text { Emirates }\end{array}$ & 7 & Libya & 1 \\
\hline France & 40 & Chile & 6 & Mozambique & 1 \\
\hline Italy & 40 & Ireland & 6 & Nepal & 1 \\
\hline Norway & 38 & Turkey & 6 & Oman & 1 \\
\hline Denmark & 36 & Greece & 5 & Poland & 1 \\
\hline Israel & 33 & Japan & 5 & $\begin{array}{l}\text { Principality } \\
\text { of } \\
\text { Liechtenstein }\end{array}$ & 1 \\
\hline India & 28 & Hungary & 4 & Qatar & 1 \\
\hline Spain & 26 & Indonesia & 4 & Serbia & 1 \\
\hline Saudi Arabia & 24 & Pakistan & 4 & Ukraine & 1 \\
\hline South Korea & 20 & Yugoslavia & 4 & Vietnam & 1 \\
\hline Switzerland & 20 & Czechoslovakia & 3 & Zimbabwe & 1 \\
\hline Thailand & 17 & Ghana & 3 & & \\
\hline Brazil & 16 & Nigeria & 3 & & \\
\hline
\end{tabular}

Based on the findings, it can be extrapolated that more active global research networks among researchers in both developed and developing countries are required for better understanding and dissemination of global PM insights and experience. Indeed, various international projects requiring the utilisation of a global resource pool have been increasingly initiated, and research related to an international project started gaining attention from academia from 1999 onward. Consequently, global research collaborations to tackle issues in various international projects where various global workforces were involved have gained the momentum, and it is reflected in the trend of research publication as shown in Table 2. More research has been conducted in collaboration with developed and developing countries to apply project lessons learned from projects that developed countries have already carried out before developing countries begin similar work. 
Table 2 Research Collaboration Profile led by Three Major Developed Countries

\begin{tabular}{|c|c|c|c|}
\hline Australia & UK & US & Note \\
\hline Canada & Canada & Canada & \multirow{7}{*}{$\begin{array}{l}\text { Countries } \\
\text { collaboration with } \\
\text { all three major } \\
\text { developed countries }\end{array}$} \\
\hline China & China & China & \\
\hline German & German & German & \\
\hline Hong Kong & Hong Kong & Hong Kong & \\
\hline Saudi Arabia & Saudi Arabia & Saudi Arabia & \\
\hline $\begin{array}{l}\text { United Arab } \\
\text { Emirates }\end{array}$ & $\begin{array}{l}\text { United Arab } \\
\text { Emirates }\end{array}$ & $\begin{array}{l}\text { United Arab } \\
\text { Emirates }\end{array}$ & \\
\hline Norway & Norway & Norway & \\
\hline Croatia & Australia & Australia & \multirow{2}{*}{$\begin{array}{l}\text { Countries } \\
\text { collaboration with } \\
\text { UK and US }\end{array}$} \\
\hline France & Brazil & Brazil & \\
\hline Finland & Finland & Armenia & \multirow{7}{*}{$\begin{array}{l}\text { Countries } \\
\text { collaboration with } \\
\text { Australia and UK }\end{array}$} \\
\hline Indonesia & Indonesia & Belgium & \\
\hline Malaysia & Malaysia & Denmark & \\
\hline Netherlands & Netherlands & Egypt & \\
\hline South Africa & South Africa & Israel & \\
\hline Spain & Spain & Jordan & \\
\hline US & US & Kuwait & \\
\hline Chile & & Chile & \multirow{6}{*}{$\begin{array}{l}\text { Countries } \\
\text { collaboration with } \\
\text { Australia and US }\end{array}$} \\
\hline South Korea & & South Korea & \\
\hline Sweden & & Sweden & \\
\hline Switzerland & & Switzerland & \\
\hline Taiwan & & Taiwan & \\
\hline UK & & UK & \\
\hline Ireland & Italy & Cyprus & \multirow{7}{*}{$\begin{array}{l}\text { Collaboration } \\
\text { with one country }\end{array}$} \\
\hline Kenya & Jordan & Ghana & \\
\hline New Zealand & Mozambique & Greece & \\
\hline \multirow[t]{4}{*}{ Russia } & Nepal & Pakistan & \\
\hline & Palestine & Singapore & \\
\hline & Portugal & Turkey & \\
\hline & & Vietnam & \\
\hline 26 & 22 & 29 & $\begin{array}{l}\text { Total number } \\
\text { of countries } \\
\text { in research } \\
\text { collaboration }\end{array}$ \\
\hline
\end{tabular}

The authorship has been evolving from a homogeneous research group comprised of a single country to a research team comprised of worldwide multiple nationalities. As shown in Table 2, the three major developed countries have collaborated with 47 other countries, which is $67 \%$ of total countries involved in the PM research over the 35 years. Although an increased number of global research collaborations has been presented in the IJPM, there is no clear indication in research trends that more research has been conducted by multi-national research teams. Thus, 
there is still room for collaboration and integration in creating a global PM knowledge asset, and tackling global PM research challenges.

The most frequently researched topics are Human Resource, communication, and procurement management, which is $53 \%$ of total PM research over 35 years as shown in Table 3. Integration management indicates almost similar volume of research to procurement management, and it counts 65\% of total PM research if the integration management is included. As shown in Figure 2, scope management does not indicate a consecutive research trend, as there were no explicit research topics or keywords related to scope management in 1983, 1987, 1990, and so on. Most of PM research has a fundamental relationship with the scope management, and the relationship has not been explicitly addressed or expressed in the research. For example, a research project examined a new risk management approach or communication processes for better scope validation. In this case, the keywords were mainly related to risk or communication management, although the ultimate goal of the research is to improve scope validation. The ambiguity of keywords cause made it difficult to interpret scope management research trends, and thus it is recommended to explore an article further if there is any ambiguity in PM domain knowledge. In addition to the research trend of the scope management, it counts only $16 \%$ of total PM research when the triple constraint or iron triangle (scope, time, and cost management) are only counted.

The quality management gained a momentum in research between 1994 and 1995. As there are needs to develop a quality standard in PM that can be used as a communication base for a global project, the global PM Body of Knowledge and Standard was researched in Australia, Canada, Netherlands, UK, and US in 1995. As a result, quality management gained much attention from PM researchers in various countries. From 2013 onward, quality management has been researched actively in the research topics related to knowledge management. By utilising lessons learned from historical data, a company or industry can strive to improve the quality of their projects, and enhance skills and knowledge of human resources. Subsequently, there is a reciprocal research relationship with quality and HR management, and this reciprocal relationship is fostered and flourished by the technological advancements in ICT tools, including project management information systems and data repository systems. Stakeholder management was added in PM domain knowledge defined by the PM Body of Knowledge 5th edition in 2012. Although stakeholder management is explicitly defined and included in the PM domain knowledge, PM research related to stakeholder engagement and management has been conducted as a subcategory of HR management or communication management before 2012 .

The PM research pattern is presented as it requires more integrated perspective of research questions such as quality and HR management or risk and scope management. Furthermore, it is important to examine PM research trends based on a holistic perspective by escaping from an ad hoc and black and white approach. It is evident that there is a correlation between PM research and industry or society. Therefore, the influences of PM research and industry, and how PM research leads industry to project successes by tackling issues can be more clearly understood by comparing the PM research trends to socioeconomic events over the year. As shown in Table 3, there have been global issues and technological advances that have influenced societies and the world. In order to identify the global issues, reports released by the United Nations from 1980 to 2016 were reviewed, and keywords search for matching the PM research and global issue trends was utilized. 
U T S

e P R E S S
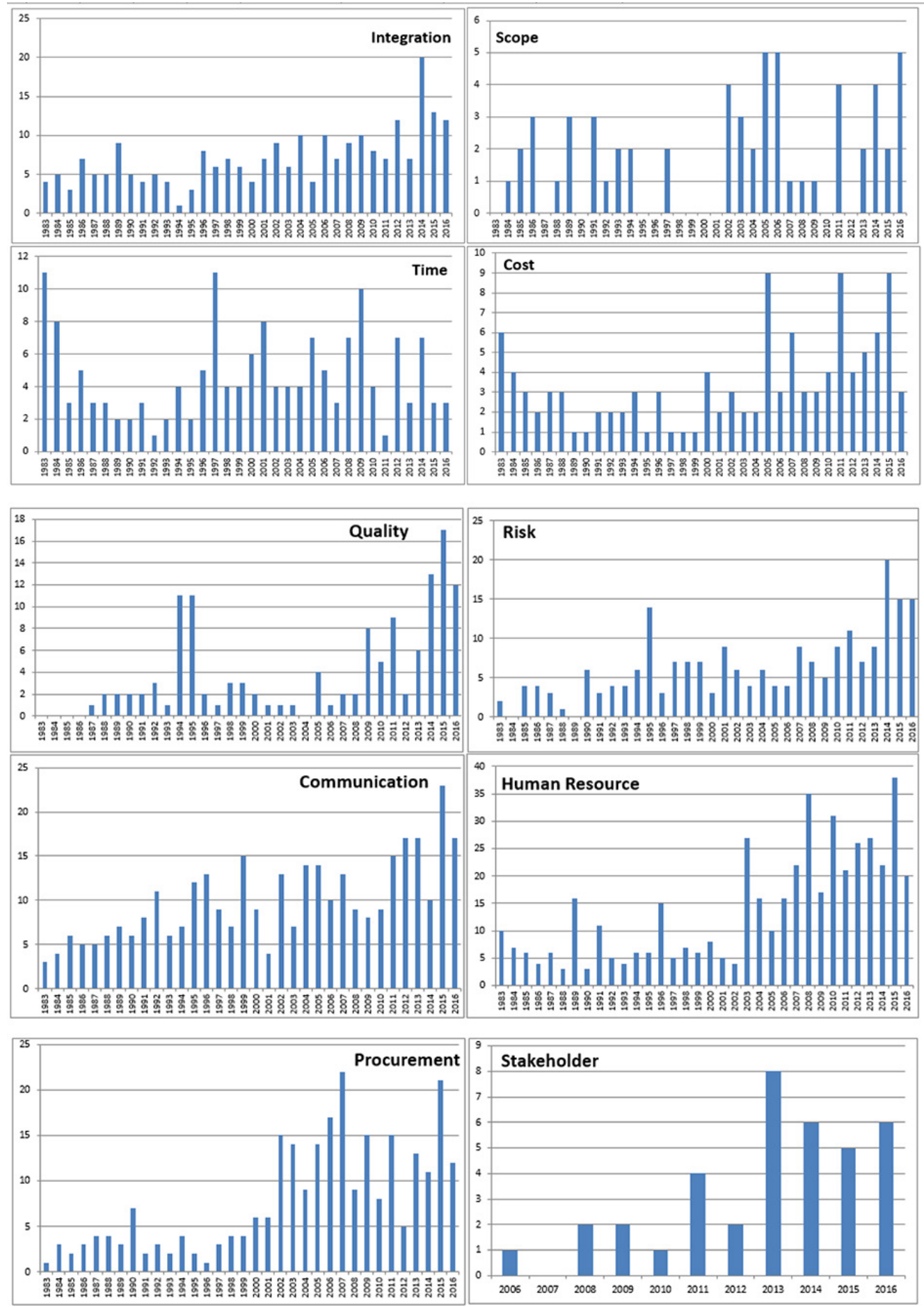

Figure 2 Trends of PM Research based on PM Domain Knowledge

Communication has been researched frequently, and research questions were mainly focused on a specific location or an organization based project, until the internet has become the main medium for communication in the industry. In particular, incremental developments of communication technologies related to the internet were made between 1992 and 1999, and a project team could be dispersed as, they could communicate via internet and video telephone. As a result, research to improve communication among a dispersed project team started, 
and the amount of research focusing on communication indicates the increasing pattern in accordance with the events such as the invention of world wide web and the installation of the transatlantic fibre optic communication system. In addition, as there was a prediction that failure of computer based systems may lead the entire world to destruction due to the Y2K bug, increased research on communication management to mitigate miscommunication of information was carried out between 1998 and 2000 as shown in Figure 2.

Various construction projects were initiated, requiring global HR and collaboration, such as the Channel tunnel construction project in collaboration with UK and France in 1986. The terms 'international project' and 'mega project' were presented for the first time in the IJPM in 1991 and 1994 respectively. As new approaches to international projects and mega projects are required, research in industry, HR and project delivery methods for the context have been conducted actively. Consequently, international project management was researched in relation to various PM knowledge domains, including communication, procurement, and quality management in Sweden 1991, and Singapore, UK, and the US in 1992, and this research trend continued from 1994 to 1996 in a broader range of research topics related to quality, integration, risk, HR, and communication management. In alignment with global projects, the global PM Body of Knowledge and Standard researched in Australia, Canada, Netherlands, UK, and the US in 1995.

Table 3 Research trends and socioeconomic events over 35 years

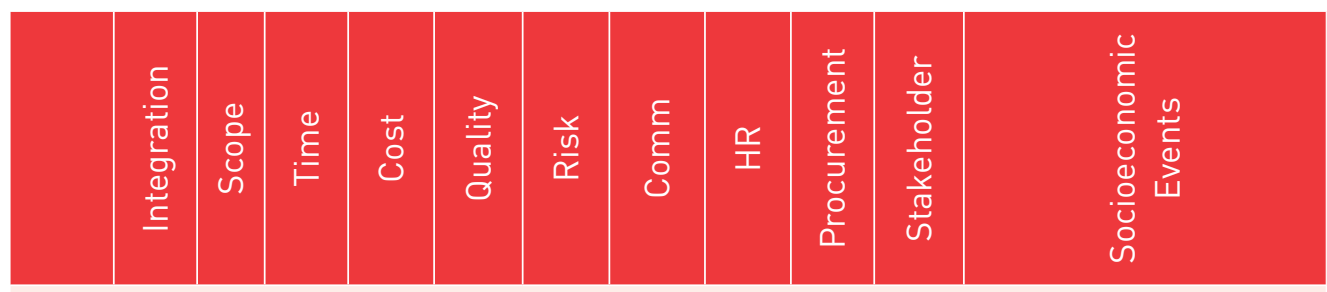

IBM released the first PC using MS DOS, and the term 'Internet' mentioned for the first time in 1981.

\begin{tabular}{|c|c|c|c|c|c|c|c|c|c|c|c|}
\hline 1983 & 4 & 0 & 11 & 6 & 0 & 2 & 3 & 10 & 1 & 0 & $\begin{array}{l}\text { MS Word released for } \\
\text { the first time }\end{array}$ \\
\hline 1984 & 5 & 1 & 8 & 4 & 0 & 0 & 4 & 7 & 3 & 0 & $\begin{array}{l}\text { Apple Macintosh } \\
\text { released in the } \\
\text { market }\end{array}$ \\
\hline 1985 & 3 & 2 & 3 & 3 & 0 & 4 & 6 & 6 & 2 & 0 & \\
\hline 1986 & 7 & 3 & 5 & 2 & 0 & 4 & 5 & 4 & 3 & 0 & $\begin{array}{l}\text { UK and France } \\
\text { announced a plan for } \\
\text { the Channel Tunnel }\end{array}$ \\
\hline 1987 & 5 & 0 & 3 & 3 & 1 & 3 & 5 & 6 & 4 & 0 & \\
\hline 1988 & 5 & 1 & 3 & 3 & 2 & 1 & 6 & 3 & 4 & 0 & $\begin{array}{l}\text { The first transatlantic } \\
\text { fibre optic cable } \\
\text { system installed }\end{array}$ \\
\hline 1989 & 9 & 3 & 2 & 1 & 2 & 0 & 7 & 16 & 3 & 0 & \\
\hline 1990 & 5 & 0 & 2 & 1 & 2 & 6 & 6 & 3 & 7 & 0 & $\begin{array}{l}\text { 16-megabit memory } \\
\text { chip released }\end{array}$ \\
\hline
\end{tabular}


Table 3 continued

\begin{tabular}{|c|c|c|c|c|c|c|c|c|c|c|c|}
\hline 1991 & 4 & 3 & 3 & 2 & 2 & 3 & 8 & 11 & 2 & 0 & $\begin{array}{l}\text { a) The first web } \\
\text { browser introduced } \\
\text { b) The term } \\
\text { 'International Project' } \\
\text { used for the first time } \\
\text { by Sweden }\end{array}$ \\
\hline 1992 & 5 & 1 & 1 & 2 & 3 & 4 & 11 & 5 & 3 & 0 & $\begin{array}{l}\text { AT\&T released the } \\
\text { first video telephone }\end{array}$ \\
\hline 1993 & 4 & 2 & 2 & 2 & 1 & 4 & 6 & 4 & 2 & 0 & $\begin{array}{l}\text { a) World Wide Web } \\
\text { invented } \\
\text { b) Human embryo } \\
\text { cloned for the first } \\
\text { time in US }\end{array}$ \\
\hline 1994 & 1 & 2 & 4 & 3 & 11 & 6 & 7 & 6 & 4 & 0 & $\begin{array}{l}\text { a) The Channel } \\
\text { Tunnel project } \\
\text { completed } \\
\text { b) The term 'Mega } \\
\text { Project' used } \\
\text { c) Portfolio } \\
\text { management } \\
\text { mentioned for the } \\
\text { first time in IJPM }\end{array}$ \\
\hline 1995 & 3 & 0 & 2 & 1 & 11 & 14 & 12 & 6 & 2 & 0 & $\begin{array}{l}\text { a) Global PM Body } \\
\text { of Knowledge and } \\
\text { Standard researched } \\
\text { in Australia, Canada, } \\
\text { Netherlands, UK, and } \\
\text { US } \\
\text { b) Ebay started the } \\
\text { online auction and } \\
\text { shopping }\end{array}$ \\
\hline 1996 & 8 & 0 & 5 & 3 & 2 & 3 & 13 & 15 & 1 & 0 & \\
\hline 1997 & 6 & 2 & 11 & 1 & 1 & 7 & 9 & 5 & 3 & 0 & \\
\hline 1998 & 7 & 0 & 4 & 1 & 3 & 7 & 7 & 7 & 4 & 0 & $\begin{array}{l}\text { a) Google founded } \\
\text { b) E-commerce via } \\
\text { internet began }\end{array}$ \\
\hline 1999 & 6 & 0 & 4 & 1 & 3 & 7 & 15 & 6 & 4 & 0 & $\begin{array}{l}\text { The year } 2000 \text { issues } \\
\text { as known as Y } 2 \mathrm{~K} \\
\text { millennium bug } \\
\text { became the most } \\
\text { critical world wide } \\
\text { issues to be tackled }\end{array}$ \\
\hline 2000 & 4 & 0 & 6 & 4 & 2 & 3 & 9 & 8 & 6 & 0 & \\
\hline 2001 & 7 & 0 & 8 & 2 & 1 & 9 & 4 & 5 & 6 & 0 & $\begin{array}{l}\text { Wikipedia went } \\
\text { online }\end{array}$ \\
\hline
\end{tabular}


Table 3 continued

\begin{tabular}{|c|c|c|c|c|c|c|c|c|c|c|c|}
\hline 2002 & 9 & 4 & 4 & 3 & 1 & 6 & 13 & 4 & 15 & 0 & $\begin{array}{l}\text { The Mars Odyssey } \\
\text { (NASA Mars } \\
\text { Exploration) found } \\
\text { signs of water and ice } \\
\text { on the Mars }\end{array}$ \\
\hline 2003 & 6 & 3 & 4 & 2 & 1 & 4 & 7 & 27 & 14 & 0 & $\begin{array}{l}\text { Human genome } \\
\text { project successfully } \\
\text { completed }\end{array}$ \\
\hline 2004 & 10 & 2 & 4 & 2 & 0 & 6 & 14 & 16 & 9 & 0 & $\begin{array}{l}\text { Building 'Taipei 101' } \\
\text { opened in Taiwan }\end{array}$ \\
\hline 2005 & 4 & 5 & 7 & 9 & 4 & 4 & 14 & 10 & 14 & 0 & \\
\hline 2006 & 10 & 5 & 5 & 3 & 1 & 4 & 10 & 16 & 17 & 1 & \\
\hline 2007 & 7 & 1 & 3 & 6 & 2 & 9 & 13 & 22 & 22 & 0 & $\begin{array}{l}\text { Apple introduced the } \\
\text { iPhone }\end{array}$ \\
\hline 2008 & 9 & 1 & 7 & 3 & 2 & 7 & 9 & 35 & 9 & 2 & $\begin{array}{l}\text { Bankruptcy of } \\
\text { Lehman Brothers }\end{array}$ \\
\hline 2009 & 10 & 1 & 10 & 3 & 8 & 5 & 8 & 17 & 15 & 2 & $\begin{array}{l}\text { The 3rd generation } \\
\text { (3G) mobile network } \\
\text { continue to grow and } \\
\text { enhanced }\end{array}$ \\
\hline 2010 & 8 & 0 & 4 & 4 & 5 & 9 & 9 & 31 & 8 & 1 & \\
\hline 2011 & 7 & 4 & 1 & 9 & 9 & 11 & 15 & 21 & 15 & 4 & \\
\hline 2012 & 12 & 0 & 7 & 4 & 2 & 7 & 17 & 26 & 5 & 2 & $\begin{array}{l}\text { a) Stakeholder } \\
\text { Management added } \\
\text { in PM Domain } \\
\text { Knowledge for the } \\
\text { first time } \\
\text { b) Project } \\
\text { Governance (Program } \\
\text { and Portfolio } \\
\text { Management) } \\
\text { mentioned for the } \\
\text { first time }\end{array}$ \\
\hline 2013 & 7 & 2 & 3 & 5 & 6 & 9 & 17 & 27 & 13 & 8 & $\begin{array}{l}\text { Project governance } \\
\text { started gaining } \\
\text { attention }\end{array}$ \\
\hline 2014 & 20 & 4 & 7 & 6 & 13 & 20 & 10 & 22 & 11 & 6 & $\begin{array}{l}\text { Project governance } \\
\text { mainly researched in } \\
\text { various countries. }\end{array}$ \\
\hline 2015 & 13 & 2 & 3 & 9 & 17 & 15 & 23 & 38 & 21 & 5 & \\
\hline 2016 & 12 & 5 & 3 & 3 & 12 & 15 & 17 & 20 & 12 & 6 & \\
\hline Total & 240 & 58 & 157 & 115 & 129 & 217 & 337 & 463 & 262 & 37 & $\begin{array}{l}\text { Total number of } \\
\text { research conducted } \\
\text { in each domain } \\
\text { knowledge over } 35 \\
\text { years }\end{array}$ \\
\hline
\end{tabular}


U T S

e P R E S S

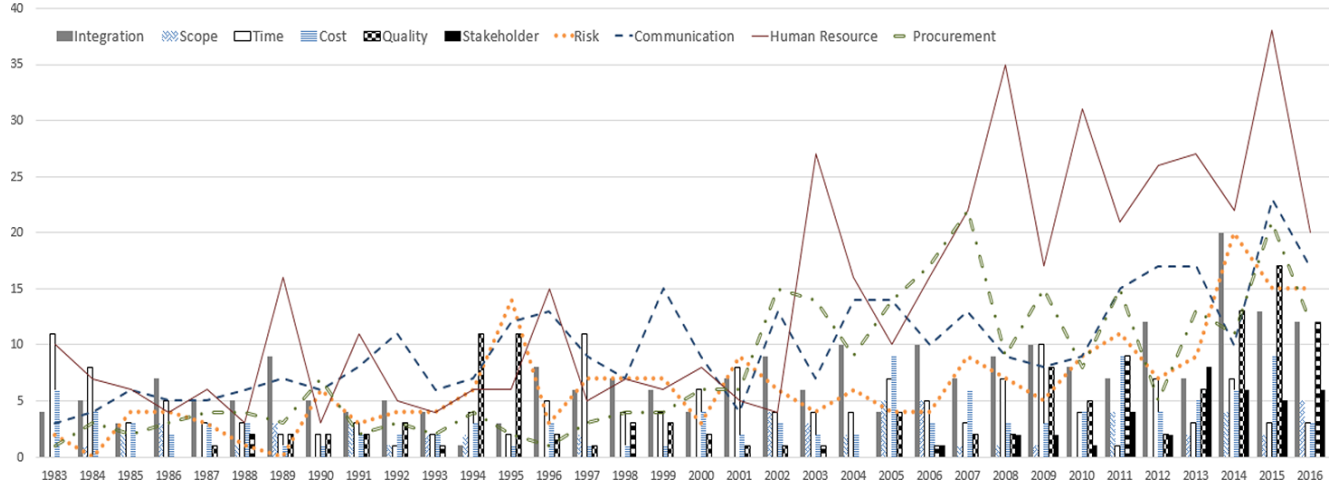

Figure 3 Research trends of PM domain knowledge

Information exchange among project team members through a technological medium was researched in the UK in 1984, and computer based learning for the systems engineering was an outcome of the research. With technology advancements, industry rapidly adopted technologies in their practices, and as one of engineering disciplines, system engineering adopted the computer based learning system for more effective and efficient engineering works in the manufacturing and engineering sectors, such as a fighter jet engineering. As the alignment of project(s) with corporate strategy has become more important, the term 'project governance' has been mentioned for the first time in the IJPM in 2012. Project governance is essential to align various projects with corporate strategy. It requires stakeholder and risk management in conjunction with scope management for portfolio and programme level. To provide a methodology for industry, various methodological scope management research has been conducted. Consequently, the practical needs and demands for industry foster PM research related to project governance, including the integration, risk, stakeholder, and communication management as shown in Table 3. Thus, it is important to recognise a research question in a holistic viewpoint by integrating different PM domain knowledge, and tackle issues in the industry. In doing so, more integrated and practical PM research can be conducted, and contribute to establishing more globalised perspective and practical solution to the industry and society that can enhance the productivity of the industry.

\section{Conclusion}

This research attempted to broaden understanding of PM success, and respond to dynamic changes in a global PM context. In order to appreciate PM research patterns and establish a better understanding about PM success, this research aimed to identify PM research topics and trends, and reveal a correlation between global socioeconomic issues or events and PM research trends. A total of 70 countries contributed to publishing 2,015 articles, and the most frequently researched topics were HR, communication, and procurement. $41 \%$ (828 articles) of total articles were written based on developed countries including the UK, US and Australia.

For a better understanding of global PM insights, more global collaborations among researchers in both developed and developing countries are required. Based on the finding, it can be considered that PM research topics and the socioeconomic events have a correlation, although the quantified level of correlation is not fully examined in this study as it is outside the research scope. PM research trends have become more globalised, and head toward a multi-national research collaboration. The continuous technological advancements in ICT, which is particularly related to communication, foster research collaboration and emphasize more on the effective HR research through better communication. 
It is expected that more integrated and practical PM research will be conducted by various researchers with various nationalities, and contribute to establishing a more globalised perspective and practical solutions to industry for productivity enhancement. This research will contribute to understanding the PM research trends in conjunction with socioeconomic perspective, and serve as a stepping stone to develop further research on PM research trends and correlation with socioeconomic events in a quantified manner.

\section{References}

Aaron, J.M, (2005), Project Management and Economic Growth: A 21st Century Competitive Strategy for Technology-Based Industries, Available at: http://milestoneplanning.net/whitepapers/Project\%20 Management\%20and\%20economic\%20growth3.pdf [Accessed 19 July 2017].

Archibald, R.D. (2003). Managing High-Technology Programs and Projects, 3rd Ed. Wiley \& Sons, NY, US.

Betts, M. and Lansley, P. (1995). International Journal of Project Management: a review of the first ten years, International Journal of Project Management, 13 (4), pp. 207-217.

Clarke, T. and Clegg, S. (1998). Changing paradigms: The transformation of management knowledge for the 21st century. London: Harper Collins.

Crawford, L., Pollack, J., England, D. (2006). Uncovering the trends in project management: Journal emphases over the last 10 years, International Journal of Project Management, 24 (2006), pp. 175-184

Crawford, J.K. and Pennypacker, J.S. (2000). The Value of Project Management: Why Every 21st Century Company Must Have an Effective Project Management Company, Proceedings of the PMI 2000 Seminars \& Symposium, Houston, TX.

Evaristo, R. and van Fenema, P. C. (1999). A typology of project management: emergence and evolution of new forms, International Journal of Project Management, 17 (5), pp. 275-281.

Ilter, D. and Ergen, E. (2015). BIM for building refurbishment and maintenance: current status and research directions, Structural Survey, 33 (3), pp. 228-256.

ISO (2012). ISO 21500:2012 - Guidance on project management, ISO.

Jeong, C. and Kim, J. (2012). Analysis of trend in construction using text mining method, Journal of The Korean Digital Architecture and Interior Association, 12 (2), pp. 53-60.

Kloppenborg, T. J., Opfer, W.A. (2000). Forty years of project management research: Trends, interpretations, and predictions, In: PMI Research Conference 2000: Project Management Research at the Turn of the Millennium, Paris, France, pp. 41-59.

Lu, Y., Li, Y., Skibniewski, M., Wu, Z., Wang, R., Le, Y. (2015). Information and communication technology applications in architecture, engineering, and construction organizations: a 15-year review, Information and Communication Technology (ICT) in AEC Organizations: Assessment of Impact on Work Practices, Project Delivery, and Organizational Behavior, pp. 1-19.

Pascale, R. (1990). Managing on the edge. London: Penguin.

PMI (2017). Project Management Job Growth and Talent Gap 2017-2027, PMI, Newtown Square, PA, US.

Stretton, A. (2000). An investigation of connections between organisational change and project management. In: IRNOP IV Conference - Paradoxes of Project Collaboration in the Global Economy: Interdependence, Complexity and Ambiguity, Sydney. Australia. 
Shenhar, A. (1996). Project Management Theory: The road to better practice, In: Project Management Institute 27th Annual Seminar/Symposium, Chicago, US.

Themistocleous, G., and Wearne, S.H. (2000). Project management topic coverage in journals. International Journal of Project Management, 18 (1), pp. 7-11.

Urli, B., Urli, D. (2000). Project management in North America, stability of the concepts. Project Manage Journal, 31 (3), pp. 33-43.

Volk, R., Stengel, J. and Schultmann, F. (2014). Building information modelling (BIM) for existing buildings: literature review and future needs, Automation in Construction, 38 (2014), pp. 109-127.

\section{About the Authors}

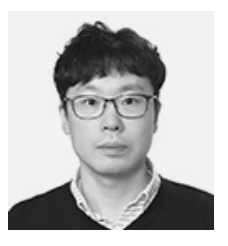

Ki Pyung Kim is Lecturer in the School of Natural and Built Environments at the University of South Australia.

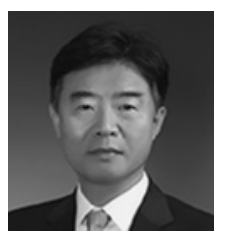

Chang Wook Kang is Professor in the Department of Industrial and

Management Engineering at Hangyang University, Republic of Korea. 